\title{
Livspolitik och existentiell mening i ett alternativsamhälle på landsbygden
}

\author{
Exemplet Uddebo
}

\section{Life politics and existential meaning in an alternative rural society. The example of Uddebo.}

This article explores the existential driving forces to develop an economically, socially, and ecologically sustainable alternative rural space, where circular economy, self-sufficiency and work-critical attitudes prevail. By focusing on 15 individual narratives, we analyze concrete practices and shared efforts as a road to an alternative local community and an existentially meaningful everyday life. The analysis is framed by an existential sociological perspective and by Beck's idea of the Children of Freedom in second modernity. By developing a life-political approach where "less is more", the interviewees both want to achieve a meaningful life in the present and build a sustainable society for future generations. The goal is for everyone to decide for themselves about their time use and finding collective solutions to individual problems, creating a space where existential meaning replaces the lived experience of meaninglessness in the consumer- and working society. However, the attempts to establish an alternative rural society also contain dilemmas and conflicts related to finding independent organizing and financing opportunities.

Keywords: life politics, alternative rural space, sustainability, existential meaning, Children of Freedom

\section{Inledning}

Den här artikeln handlar om ett antal personers strävan efter att skapa ett meningsfullt liv på landsbygden, bortom det övergripande samhällets normer om lönearbete och konsumtion. Vi tar del av deras tankar om livet i Uddebo, en liten ort i Västra Götaland. Till skillnad från många andra landsbygdsorter har invånarantalet här ökat under de senaste åren. Flera inflyttade är unga med kulturintresse som när en dröm om ett samhälle där självhushållning och arbetskritiska förhållningssätt råder.

Vi analyserar intervjuberättelser från 15 personer, alla inflyttade eller återinflyttade till Uddebo. Utifrån ett existenssociologiskt perspektiv, som sätter människans existentiella meningssökande i förgrunden, undersöker vi drivkrafter för att söka sig till platsen. Frågor vi ställer är hur existentiellt meningsskapande är förbundet med lokalt utvecklade metoder för att bygga ett hållbart alternativsamhälle, det vill säga ett samhälle som värnar såväl den egna livsmiljön som kommande generationers resurser. 
Artikelns tema är således hur hållbarhet kan formas genom levd erfarenhet, konkreta praktiker och gemensamma projekt. Läsaren får ta del av berättelser om hur ett antal personer strävar efter att utveckla nya livsmönster i ett alternativt samhälle, hur de med Becks (1998, 2000[1986]) ord utvecklar en vardaglig livspolitik som de vill göra bestående bortom det kapitalistiska arbetssamhället.

I artikeln beskrivs hur livspolitiken utvecklats underifrån och med gemensamma krafter. Men vi pekar också på hot mot den alternativa livsföringen som de intervjuade identifierat: att ställa sig utanför det övriga samhällets normer kräver resurser. Oenighet kan uppstå inom gruppen om vilken väg Uddebo ska ta i framtiden och vilka som ska ta ut riktningen. Liknade problem känns igen från tidigare studier av alternativsamhällen och sociala rörelser (se t.ex. Ekberg 2016; Peterson 2019).

Även om vi jämför de intervjuades liv i Uddebo med urbana alternativsamhällen, är avsikten här att sätta landsbygden i centrum. Enligt Tillmar (2019:222) saknas forskning om svenska förhållanden som just analyserar "lokalsamhällen på landsbygden som spirar och utvecklar alternativa visioner, och som till och med har en inflyttning på grund av detta”. Därtill behövs analyser som utmanar dominerande föreställningar om att landsbygden i motsats till staden bebos av en homogen grupp och att möten och meningsskiljaktigheter här lyser med sin frånvaro (Forsberg, Lundmark \& Stenbacka 2012). Artikeln kan betraktas som ett försök att anta denna utmaning med fokus på betydelsen av existentiellt meningsskapande i en del av den livspolitik som utvecklats i Uddebo.

Vi inleder med ett avsnitt om våra analytiska utgångspunkter. Därefter kommer ett metodavsnitt, som följs av den empiriska analysen. I artikelns avslutning går vi in på varför en sociologisk analys som sätter landsbygden i centrum är väsentlig och vad ett existenssociologiskt perspektiv kan tillföra studier av alternativsamhällen.

\section{Forskningskontext och analytiska utgångspunkter}

I artikeln studeras visioner, praktiker och metoder som kan uppkomma i ett ruralt alternativsamhälle i strävan att skapa ett hållbart livssammanhang. Med detta menar vi ett liv som för individen eller gruppen framstår som meningsfullt och samtidigt inte uttömmer resurser för kommande generationer. I det sammanhanget närmar vi oss frågan om hur landsbygdsmiljöer, som den i Uddebo, kan erbjuda specifika villkor för formandet av en fungerande livsmiljö och en meningsfull vardag.

\section{Att studera rurala alternativsamhällen}

Enligt Massey (2007) är platser en del av ett globalt och relationellt nätverk. Det betyder att de maktresurser och förståelsehorisonter som människor utvecklar i lokala sammanhang alltid är beroende av tolkningar och resurser som dominerar på andra orter och i andra städer. Massey poängterar att storstäderna har ekonomiskt och symboliskt företräde i den globala kapitalismen. Exempel på detta är att andelen arbetstillfällen i Sverige alltmer kommit att koncentreras till huvudstadsområdet (Eurofound 2019) och att främst landsbygdskommuner ställs inför krav på strukturomställningar 
för att bli "attraktiva" som inflyttningsorter (Rönnblom 2016). Invånartäthet ses per se som något eftersträvansvärt, samtidigt som glesbygdspolitik tenderar att reduceras till frågor om skattereduktion, näringslivsstöd och priser på drivmedel (Brorström \& Parment 2017), alternativt attraktionskraft som turistorter (Carlén 2017).

Exempel på samtidens urbana prerogativ tas upp i Uddbäcks (2021) studie av ungas liv och framtid i en svensk småstad. Uddbäck pekar på hur ungas val kringskärs av vad hon utifrån Ferrugia (2016) benämner ett mobilitetsimperativ, alltså kulturella föreställningar om att den framgångsrike rör sig bort från landsbygden. Den som däremot stannar kvar har gett upp hoppet om både klassresa och möjlighet till ny stimulans.

Att landsbygden förhåller sig som "den andre" till storstaden framkommer även i Ekbergs (2016) historiska analys av rurala alternativsamhällen och urbana kollektiv i 1970-talets Sverige. När alternativa grupper flyttade till landsbygden motiverade de ofta detta med att de ville distansera sig från storstadens moderna samhällsliv och forma en mer "genuin" livsmiljö. Samtidigt kunde de rurala alternativgrupperna själva uttrycka uppfattningar om staden som politikens centrum.

Enligt Halfacree (2007) återspeglas det urbana prerogativet även inom forskningen, där rurala radikala grupper ofta analyserats som ett svar på sina urbana föregångare. Trots kritiken avvisar Halfacree inte urbanforskningen, utan låter sig inspireras av Lefebvres (1991[1974]) analyser, där marginaliserade och resurssvaga gruppers erfarenheter - oavsett om de lever urbant eller ruralt - utgör platsanalysens utgångspunkt. I denna anda understryker Halfacree vikten av att belysa platsens specifika livsföring, där försök att leva enligt visionen om ett annat samhälle både kan hota och krocka med det liv som andra invånare på orten lever.

För Halfacree innebär den globala hierarkin mellan storstad och landsbygd att orter inte kan bestämmas utifrån geografisk placering. Platser bör snarare definieras utifrån hur de framställs i kunskapsproducerande sammanhang samt i politiska analyser och beslut. Därtill bör definitionen utgå från erfarenheterna hos de människor som bor på dessa platser, en utgångspunkt som vi delar med Halfacree. Detsamma gäller premissen om att landsbygden alltid bebos av flera olika grupper, både nyinflyttade och etablerade. Det ska därför understrykas att den livspolitik och det arbetskritiska förhållningssätt som beskrivs i de empiriska avsnitten endast utgör de intervjuades vardag, vilket är en av flera möjliga livsformer på orten.

På landsbygden, skriver Halfacree, är möten och samtal mellan olika grupper ofrånkomliga. Enligt Cras (2017) utgör just det samverkande - eller till och med kommunitära - en väsentlig riktlinje som invånarna på landsbygden många gånger måste rätta sig efter. Förhållandet har förstärkts i en tid då välfärdsservice och kommunikationer nedmonterats och ersatts av privata och civilsamhälleliga alternativ (Berglund, Johansson \& Molina 2005). Som Cras ser det leder detta till att privata investerare verkar i det urbana rummet, medan en fungerande välfärd på landsbygden är beroende av rörelser, föreningar och lokal gemensam organisering. Som vi ser det kan detta ge utrymme för alternativa sociala, ekonomiska och ekologiska lösningar på samtida samhällsutmaningar. 


\section{Ett existenssociologiskt perspektiv}

När det gäller den rumsliga maktordning som tecknats ovan har idéer om livskvalitet och hållbar utveckling på landsbygden ofta utgått ifrån färdiga modeller, där ökad inflyttning och attraktivitet, höjd utbildningsnivå, förbättrade hälsotal, turism, entreprenörskap och teknikutveckling tycks utgöra kärnan (Vallström 2014; Brorström \& Parment 2017; Carlén 2017). Vad vi i stället här vill belysa är de existentiella drivkrafter som kan finnas för att flytta till landsbygden och utveckla alternativa livsformer, och hur det urbana tolkningsföreträdet därmed motverkas underifrån. I artikelns empiriska avsnitt ska vi se hur en vardaglig livspolitik kan utvecklas med olika samarbetsformer, grundade i idéer om ett samhälle bortom lönearbete, konsumtion och ägande, med drömmar om ett annat samhälle än det som storstaden erbjuder.

I artikeln utforskas frågor om vikten av att känna sig delaktig och uppleva sig stå i centrum för sin egen plats och livsmiljö. Analysen känns igen från både urbansociologisk (se t.ex. Lefebvre 1991[1974]) och kulturgeografisk teoribildning (se t.ex. Tuan 2011), men berör också väsentliga existentiella teman. I analysen av detta utgår vi från ett sociologiskt perspektiv som fokuserar människors drivkrafter och sökande efter en existentiellt meningsfull vardag. Ett sådant perspektiv utvecklades i USA under 1970-talet, då ett antal sociologer, med Douglas i spetsen, kritiserade dominerande sociologiska traditioner för att åsidosätta det sociala livets existentiella meningssökande och oförutsägbarhet. Som samhällsvarelse söker vi meningsfulla praktiker, men vi möter också meningslöshet och bär på gåtor som vi aldrig löser (Douglas \& Johnson 2010[1977]).

Inom existenssociologi förespråkas ofta en analys där riktningen i människors livsbanor analyseras över tid (Flisbäck 2014. Jfr Jackson 2005; Baert, Morgan \& Ushiyama 2021). En grundtanke inom den tidiga existenssociologin är att människan alltid är på väg mot något (Douglas \& Johnson 2010[1977]). Idén känns igen från existentialismen, som tolkar den mänskliga existensen som en rörelse mot det möjliga. Det enda vi säkert vet är att mänsklig tillblivelse leder i riktning mot ändligheten (se t.ex. Heidegger 2013[1927]). Tanken skiljer sig från sociologins gängse föreställning om tid, där resurser från det förflutna, förbundna med klass, kön, "ras" och etnicitet, ofta betraktas som avgörande för vår livsföring i nuet (se t.ex. Bourdieu 2004[1979]).

Den existenssociologi som utvecklades under 1970-talet gick långt i fråga om människors improvisationsmöjligheter och förmåga att ordna snarare än att anpassa sina liv. Om existensfilosofer hävdat att människan hellre ser framtida begränsningar och risker, än att uttömma öppenhetens möjligheter och chanser, så har Flisbäck (2014) betonat vikten av att analysera de omständigheter under vilka människor omformar existentiellt meningssökande eller anpassar det efter givna sociala förhållanden (se även Jackson 2005).

Den som i dag tar sig an de tidiga existenssociologernas perspektiv kan finna att polemiken mot dåtida perspektiv får stort utrymme, oavsett om det gäller strukturfunktionalismen eller etnometodologin, som båda anses lägga för stor vikt vid att avtäcka dolda sociala ordningar (Douglas \& Johnson 2010[1977]). Osäkerhet har också blivit ett alltmer dominerande tema inom sociologin. Under 1980-talet analyserade 
exempelvis Beck hur ett så kallat risksambälle utvecklats under en andra modernitet. I denna form av samhälle har det moderna samhällets vetenskapliga kalkylerande och välfärdsstatens strävan efter både jämlikhet och produktivitet slagit tillbaka i ekologiska faror och osäkra arbetsmarknader. Traditionernas vägledning $\mathrm{i}$ individens framtidsprojekt har förbytts mot en uppsjö av valmöjligheter med osäkerhetskänslor som följd. ${ }^{1}$

Osäkerhet och sökande efter existentiell mening är kanske inte längre ett undanträngt perspektiv i sociologin. Men som Kotarba (2002) påpekat innebär det senkapitalistiska samhällets ökade hastighet och tilltagande individualiseringsprocesser ett antal osäkerhetsmoment som gör existenssociologiska perspektiv mer aktuella än de var när de växte fram. Det behövs perspektiv som analyserar hur individer hanterar flyktiga livssituationer och söker platser som erbjuder existentiell mening och kollektiva resurser för att hantera osäkerhet. Som vi ska se framträder Uddebo i de intervjuades berättelser just som en sådan plats för nya livsmönster och ny livsföring - som ett existentiellt möjlighetsrum.

\section{Existentiellt imperativ och utvecklandet av en livspolitik}

Central i det existenssociologiska perspektiv som vi anlägger här är analysen av hur människor placerar sig i ett vidare livssammanhang. Ytterst handlar det om alla de kollektiva och individuella sätt på vilka människor försöker sätta avtryck med förhoppning om att lämna något efter sig. En utgångspunkt är att frågor om existentiell mening kan förstärkas i kritiska situationer eller vid tillfällen då vardagen bryts (jfr Heidegger 2013[1927]). Jackson (2005) har fångat förhållandet med begreppet existentiellt imperativ, vilket berör hur meningsfrågor både väcks och konstrueras vid avgörande livsförändringar som föräldraskap, sjukdom och migration, i samband med att yrkeslivet påbörjas eller avslutas samt vid kriser eller pandemier (jfr Bengtsson \& Flisbäck 2020). Enligt Jackson blir i livets brytpunkter förgängligheten mer påtaglig än tidigare. Frågor accentueras om vad vi gjort i livet och vad vi vill göra med den tid vi tror oss ha kvar.

När vi här analyserar livspolitiken hos de intervjuade i Uddebo, förbinds denna med deras beskrivningar av existentiell mening. Vi tar del av de intervjuades strävanden efter det fulländade livet, med kollektiva ideal om att skapa ett liv bortom lönearbete och ohållbar konsumtion. Vi ser hur självutveckling och egen tillfredställelse i fråga om meningsfull vardag artikuleras parallellt med ansvar för framtiden.

Enligt Ekberg (2016) kritiserades 1970-talets alternativa rurala kollektiv för att vara egoistiska och vända sig bort från de platser där politiskt avgörande händelser inträffade. Både då och nu finns oförmåga att se hur den personliga livsföringen är

1 Andra exempel är Rosas (2014[2012]) analys av en accelererande modernitet, där kapitalismens ständigt tilltagande hastighet och sökande efter kontroll anses ha lett till upplevelsen av ett "rasande stillastående". Snarare än självutveckling upplever samhällsmedborgarna nu meningslöshetskänslor och oförmåga till vad Rosa (2020[2018]) kallar resonans, det vill säga ett existentiellt meningsfullt tillstånd där människor lyssnar och låter sig omformas i naturen eller i sociala relationer. 
politisk. På liknande tema har Beck återkommande framhållit att det inte finns någon motsättning mellan självutveckling och etiskt ansvar. Tvärtom pekar Beck (1998) på hur den parallella omsorgen om egna projekt och andras välfärd kan vara ett sätt att manövrera i den öppenhet och de risker som uppkommit i risksamhället.

De så kallade "frihetens barn" (Kinder der Freihet) är Becks (1998) begrepp för de grupper som utvecklar strategier för att vända risk till möjlighet. För när jobben ändå inte tycks räcka åt alla, och när utbildning inte är en garant för en stabil ekonomisk framtid, blir det främsta målet för frihetens barn att själva få bestämma över sin tid och framtid. De bemöter "risksamhällets ovisshet" genom att forma en livspolitik där "jagprojekten" står i centrum, men detta sker på ett socialt och ekologiskt ansvarsfullt sätt.

Vi ska återkomma till Becks tankar, men här vill vi peka på hur de existentiella frågorna intensifierats i och med den samhällskris som uppkom våren 2020 till följd av coronapandemin. När vi samlade in en stor del av intervjumaterialet gjorde $D a-$ gens Nyheter (Herold 2020) ett reportage om Uddebo som ett samhälle vilket genom återanvändning av resurser eftersträvar "cirkulär ekonomi” och där samodlingsprojekt erbjuder ett socialt och ekonomiskt skydd mot krisen.

Coronapandemin kan i sammanhanget betraktas som ett existentiellt imperativ som både synliggör och formar meningsstrukturer. Pandemin tycks väcka inte bara existentiella frågor, utan också ett behov av att ge svar på dem genom vardagliga livspolitiska handlingar. Intervjuerna återspeglar detta genom att krisen tas till intäkt för vikten av att utveckla resilienta livsformer liknande dem i Uddebo, vilket för oss vidare till frågor om studiens metod.

\section{Metod}

Artikelns material är insamlat inom ramen för projektet "Hybrida organisationer som verktyg för hållbar platsutveckling”, finansierat av Centrum för välfärdsstudier vid Högskolan i Borås. Studiens syfte är att bidra med kunskap om hur aktörer bortom privata och offentliga intressen arbetar för att främja välfärd och hållbara livsmiljöer på landsbygden.

Artikeln bygger på kvalitativa samtalsintervjuer, mellan en och två timmar långa, med 15 personer som är bosatta i Uddebo. Som alltid i kvalitativ metod har vi i urvalet strävat efter ett spektrum av berättelser och erfarenheter utifrån forskningsfrågorna (se t.ex. Charmaz 2014:108). Av de intervjuade som kommer till tals i artikeln befinner sig 13 personer inom åldersspannet 33-44 år, medan två är äldre, runt 70 år. De två äldre intervjupersonernas retrospektiva reflektioner var väsentliga för att förstå hur ackumulerade år och tidigare erfarenheter påverkar meningsskapande, även om detta inte inkluderats i analysen.

Av de 15 intervjupersonerna är tre uppvuxna i trakten, har flyttat därifrån och återvänt. De övriga intervjuade är inflyttade. Eftersom vi här vill förstå vad som kan locka med att bosätta sig och skapa en meningsfull och hållbar livsmiljö på orten Uddebo, vände vi oss till just grupperna nyinflyttade eller återinflyttade. Samtidigt 
har intervjupersonerna levt och verkat olika länge på orten. Den med kortast tid på orten har bott där knappt sex månader, den med längst tid är uppvuxen där och återinflyttad sedan cirka 15 år tillbaka. Därtill har variation eftersträvats i fråga om familjekonstellation, det vill säga om de intervjuade säger sig leva i ensamhushåll eller i sambo- eller särboförhållanden och om de, enligt utsago, befinner sig innanför eller utanför samhällets heterosexuella norm eller kärnfamiljsnorm.

\section{Etik}

Intervjuerna har spelats in och transkriberats. I samband med intervjuerna informerades intervjupersonerna om projektets syfte och materialets förvaring. Vi har avidentifierat materialet för att värna de intervjuades diskretion. Intervjupersonerna fick själva välja om de ville bli intervjuade själva eller i samtal med en vän eller partner för att stimulera varandras tankar om studiens tema. Två intervjuer genomfördes parvis, vilket betyder att artikelns empiriska material består av 13 intervjuer. I det empiriska avsnittet används en siffra som beteckning för den intervjuperson som talar. Vid de intervjuer som utförts i par har intervjupersonerna samma siffra, men de skiljs åt genom att därefter betecknas med bokstaven "a" eller " $b$ ".

I intervjuerna frågade vi efter ålder, familje-, boende- och arbetssituation samt utbildning. ${ }^{2}$ Vi efterfrågade inte könstillhörighet, då detta inte sågs som centralt för projektets frågeställningar. Att inte kategorisera de intervjuades kön efter exempelvis vår egen uppfattning om namn har i sammanhanget setts som en etisk fråga.

De intervjuade har tagit del av och i några fall kommenterat texten. Detta har varit ett sätt att hantera det etiska och epistemologiska dilemma som rör forskarens rätt att tolka och därmed göra sig till språkrör för andra människors erfarenheter. Många gånger syftar samhällsvetenskaplig forskning till att undersöka vedertagna verklighetsuppfattningar för att sätta dem i nytt ljus (Vetenskapsrådet 2017). Att låta de intervjuade kommentera tolkning och framställning kan vara ett sätt att $i$ någon mån mildra detta maktövertag. Därtill innebär förfarandet ytterligare empirisk prövning av teori och resultat (Flisbäck 2014).

\section{Intervjumetod och analys}

Inom existenssociologiska perspektiv argumenteras ibland för livshistoriska metoder som syftar till att sätta den intervjuades erfarenheter i ett bredare tids- och erfarenhetsperspektiv (se t.ex. Douglas \& Johnson 2010[1977]; Bengtsson \& Flisbäck 2021). Eftersom vi undersöker existentiella drivkrafter för att leva och verka på platsen Uddebo har vi inspirerats av biografiska analyser (t.ex. Bertaux 1981), där meningsskapande relateras till den övergripande livssituationen och där tidsperspektiven dåtid, nutid och framtid är närvarande. Med tanke på detta hade längre och uppföljande

2 Projektet har inte etikprövats. Bedömningen är att projektet inte faller under lagen då materialet inte berör känsliga personuppgifter. Studien berör förvisso frågor om existentiell mening med förhoppningar om välmående i ett hållbart samhälle. Dessa frågor tangerar dock inte intervjupersonernas personliga förhållanden vad gäller exempelvis fysisk och psykisk hälsa. 
intervjuer troligtvis gett ett mer uttömmande material. Samtidigt analyserar vi främst de intervjuades gemensamma berättelser om platsens historia, samtid och framtid i relation till deras liv. Detta innebär att vi försöker förena två olika inriktningar som dominerar narrativ analys: en mer personcentrerad metod och en mer strukturinriktad metod (Squire, Andrews \& Tamboukou 2008). I vårt fall analyseras på så vis hur övergripande, gemensamma narrativ om platsen Uddebo framträder och lägger en grund för individers erfarenhetsberättelser om vad de finner existentiellt meningsfullt.

Den narrativa metodologin kan ha särskild relevans vid studier av rörelser och alternativsamhällen, eftersom så kallade motberättelser här tycks bli framträdande. Motberättelser är ett analytiskt verktyg som syftar till att få fram intervjuutsagornas gemensamma kärnpunkter och att kategorisera motsägelser mellan dem och spänningsförhållanden inom dem. Andrews (2004) definierar motberättelser som sådana kollektiva framställningar som kontrasterar mot förväntande normer utan att utgöra deras raka motsatser. Det handlar ofta om berättelser i vardande, det vill säga prövande tankar som ofta tar spjärn mot konventioner och normer.

Det ska understrykas att många som bor i Uddebo har bott där i generationer eller flyttade dit långt innan våra intervjupersoner kom till platsen. Invånarnas heterogenitet skildras dock sällan i medierna och samma kritik kan riktas mot vår artikel. Ofta är det den nyinflyttade gruppen som får representera orten. För att hantera detta problem intervjuade vi inom ramen för projektet ytterligare ett par personer (utöver de 15 intervjupersoner vilkas berättelser utgör artikelns material) som inte var lika inbegripna i den alternativa livsföring vi strax ska beskriva. Vi förde också informella samtal med andra orts- och kommuninvånare. Samtidigt var vi tvungna att begränsa det empiriska materialet och antalet "avvikande fall", då projektet var en mindre undersökning, begränsad i tid och med liten budget.

I medierna kan Uddebo beskrivas som en ort "där olika platser förvärvas, utvecklas och ombildas för en ny typ av användning och ekonomi” (Åkerman 2020), vars invånare värderar "tid högre än pengar" och där "människor [...] vill hitta alternativa sätt att leva” (Herold 2020). Det ska påpekas att vissa av de intervjuade således är vana vid att bli utfrågade om livet i Uddebo. Här ter sig Atkinsons och Silvermans (1997:309) idé om att vi lever i ett "intervjusamhälle” relevant. I detta slags samhälle är intervjuer frekventa redskap med vilka vi tolkar våra liv och konstruerar vår historia, eller för att återvända till Halfacree (2007): En del i förståelsen av vad landsbygd är utgörs av dess representationer. Som vi ska se i det empiriska avsnittet tycks detta vara centralt för de intervjuade: antaganden och gemensamma berättelser om platsen Uddebo skapar existentiell mening. Samtidigt är alltså vår analytiska utgångspunkt att individers levda erfarenheter och meningsuppfattningar påverkar och möjliggör vad platsen Uddebo är och kan bli i framtiden. 


\section{Resultat}

\section{Inledande om det empiriska fallet}

Uddebo är beläget i Tranemo kommun ungefär fyra mil från Borås. Tvärtemot situationen på många landsbygdsorter har det skett en inflyttning de senaste åren. Mellan år 2019 och 2020 var Uddebo den ort i Tranemo kommun som växte mest (Hideng 2021). I dag bor här cirka 450 personer. I medierna framhålls ofta att vad som lockar till inflyttning är ett rikt kultur- och föreningsliv, gemensam odling och gratisaffär: "Att man har den här lilla orten i Västsverige som är så livaktig och full av kultur" (Nyberg 2019).

Vi återfinner Uddebo i en dalgång, med ån Assman och väg 156 som klyver samhället i två delar. Gula huset vid sidan av vägen fungerade tidigare som kontor och lager till en närliggande textilfabrik. I dag är det ett hus med ateljéer och gemensamma aktiviteter. Den nedlagda skolan, "Världshuset", beskrivs som en "tvärkonstnärlig plattform" och en mötesplats för såväl "kreativt som hälsofrämjande arbete". Här finns även kommunal förskola och fritidsverksamhet. I det nedlagda väveriet på över 5000 kvadratmeter ryms föreningsliv, cykelverkstad, gemensamhetskontor, yoga, småföretag, surdegsbageri och mycket annat. En småhusby håller på att byggas på mark som arrenderas av väveriets ägare. Från början var småhusbyn tänkt som ett "prova på-boende". Nu är det en förening där var och en bygger ett eget hus med en gemensam fastighet där alla har tillgång till badrum, tvätt, kök och allrum (Uddebo Uddetopia 2021). En liknande kombination av individuellt ägande och kollektivt delande utmärker flera av projekten i Uddebo. Men innan vi går in på detta behöver vi veta hur de intervjuade beskriver Uddebos historia.

\section{Det dåtida Uddebo - ett gemensamt narrativ}

När existentiell mening och livspolitiska handlingar ska formas behövs ofta en kulturell fond, en tolkningshorisont, som den enskildes berättelse placeras inom (Baert, Morgan \& Ushiyama 2021). I vårt fall betyder det att de intervjuade placerar sin vilja att leva och verka i Uddebo i en berättelse om platsen. Här är det intressant att de 15 intervjuade återger en liknande historia om Uddebo, där de själva ofta ingår på slutet. Berättelsen handlar om vad som en gång var en livaktig bygd, som gick från bruks- och jordbrukssamhälle till by i förfall för att till sist åter formas till en plats full av liv.

Den gemensamma berättelsen - narrativet - om Uddebo inleds med beskrivningar av en by som blomstrar fram till slutet av 1900-talet. Här finns bördiga jordbruk och flera företag. Det gamla Uddebo framstår som en idyll. Framför allt betonas den sociala sammanhållningen:

Man delade på jordbruksmaskinerna, man tog hand om varandra, om gamla och barn i större utsträckning. Och man stöttade varandra med det. 
Enligt den gemensamma berättelsen präglades byn av en stark gemenskap och ett ansvarstagande där även fritiden utgjorde en viktig samvaro. I motsats till hur lönearbetet beskrivs i dag framställs det dåtida Uddebo i ett idylliskt skimmer, där vi får berättat hur arbetarna cyklade till arbetet vid något av de lokala företagen. Tack vare den geografiska närheten kunde de cykla hem på lunchrasten.

Jag får för mig att det hänger kvar från, att man hade ett tänk med ett samhälle. Man ville att arbetarna skulle ha det bra. Arbetarbostäder. Fotbollen var jättestor. IP nr 5

Att kunna leva, bo och arbeta på samma plats framhålls som positivt i de intervjuades berättelser om både det dåtida och, som vi ska se, det nutida Uddebo. Detsamma gäller förståelsen av gemensamma aktiviteter och den inbördes solidariteten. I det narrativ som framträder är ofta klass-, genus- och etnicitetsskillnader nedtonade. Troligtvis var fotbollen, som nämndes ovan, framför allt männens fritidsaktivitet. Poängen i den gemensamma berättelsen är emellertid att beskriva ett Uddebo som varit inkluderande och som alltid strävat efter jämlikhet och jämställdhet:

Uddebo har alltid varit tolerant. Det har alltid varit socialdemokratiskt och väldigt tillåtande att alla människor får vara som de vill. Det har inte varit "fint" eller att man ska vara på ett speciellt sätt. IP nr 1

Betoningen av hur solidaritet och tolerans sedan länge utgjort en central del av vad Uddebo "är" kan tolkas som ett narrativ som understödjer det egna levnadssättet i Uddebo som autentiskt. Att dagens Uddebo inte av alla uppfattas som en alltigenom tolerant plats kommer vi till senare, men gemensamt för intervjupersonernas berättelser är deras beskrivning av det dåtida Uddebo som en plats för gemenskap och omtanke. Men i slutet av 1900-talet händer något: Uddebo börjar utvecklas i en annan riktning. Det Uddebo som nu tar form beskrivs inte som en idyll utan som en by i förfall. Människor flyr från platsen. Hus lämnas tomma. År 1979 stängs Konsum. År 1991 läggs Posten ner tillsammans med den sista livsmedelsbutiken. Att bo på platsen blir näst intill förknippat med "en skamsenhet, en känsla att man inte ville säga att man kom härifrån, man ville inte tillhöra den här platsen" (IP nr 1). Det berättas om utflyttningar, nedläggningar och "kriminella" och "drogmissbrukare" som flyttar till byn:

Lite på dekis. Utflyttning, nedläggning av textilindustrier. Utflyttning, många tomma hus. Det kan dra till sig olika typer av människor. [...] Kriminella och drogmissbrukare. Uddebo hade en sådan period som var jättebesvärlig, tror jag. IP nr 2

När väveriet år 2011 efter nästan 100 års verksamhet i Uddebo blev uppköpt och produktionen flyttad från orten hotades byn av den definitiva dödsstöten. Allt det som verkat enande och uppbyggligt, som varit förknippat med gemenskap, trygghet, 
solidaritet och stolthet, tycktes nu vara borta. Men vid det laget hade en person, som under en period utbildat sig och arbetat på andra platser, köpt en gård och flyttat tillbaka till orten. Hen närde en dröm om att fler skulle flytta till Uddebo så att byn skulle leva upp igen. Att vara bekant i byn gav legitimitet och gjorde det möjligt att förmedla de tomma husen till vänner och vänners vänner som ville flytta från staden. Att husens marknadsvärden var låga attraherade. Målet var att Uddebo skulle bli en plats för kulturverksamhet, självförsörjning och systemkritisk livsföring. I dag är det få om ens några hus som gapar tomma.

De som flyttade till Uddebo vid den här tiden säger att de kände sig välkomna, för nu kunde allt bara bli bättre. Citatet nedan illustrerar hur berättelsen om Uddebo således får ett "lyckligt" slut. Skammen över platsen förbyttes i stolthet. Aktiviteten och gemenskapen hade återuppväckts:

Så när det kom in människor utifrån med en positiv energi och ville göra saker så var folk väldigt välkomnande. De som alltid hade bott här. De såg att hus började restaureras eller renoveras. Det började hända bra saker igen. Så de var ju jättepositiva. Så det var verkligen inte "vilka är ni som kommer här?" Man kände sig väldigt välkommen. IP nr 3b

\section{Uddebo i dag - en plats för livspolitik och existentiell mening}

Ovan har vi återgett ett narrativ om Uddebos historia och utveckling. Detta tolkar vi som en bakgrund till det liv och den meningsfulla vardag som de intervjuade i dag säger sig eftersträva på platsen. För de intervjuade tycks narrativet med andra ord utgöra ett meningssammanhang i vilket de placerar nuvarande projekt och gemensamma praktiker, liksom en individuell livsberättelse om varför de sökt sig till orten.

När vi nu fått ta del av berättelser om vad Uddebo varit, så väcks frågan: Vad är orten i dag? Uddebo beskrivs som "en by som inte är mainstream" (IP nr 6), där människor samlats som har idéer och kraft att genomföra dem:

Här är det väldigt många som samlats på samma plats. Alltså folk som har egna idéer, är energiska. De har säkert varit jätteviktiga alltid, och i alla kulturer, men varit utspridda. IP $\mathrm{nr} 8 \mathrm{a}$

I intervjucitatet ovan sägs att många påhittiga människor ryms i Uddebo. Samtidigt menar de intervjuade att platsen är en palett av olika människor, där många sociala grupper får rum:

Jag ser inte Uddebo som homogent. Vi brukar säga att om vi gör en grov uppdelning så är det en tredjedel gamla Uddebobor, en tredjedel vanliga Svensson som flyttat dit för att det är billigt. Sedan är det en tredjedel, de tre h:na: hackers, hipsters och hippies. Kulturmänniskan. Jag tycker att det är bra att vi har en sådan blandning. IP nr 13 
I Uddebo finns enligt de intervjuade allt från punk till new age och nyare subkulturer. Kreativt verksamma ryms vid sidan av arbetare. Men är alla välkomna, eller finns det någon grupp som inte skulle kunna trivas i Uddebo? På den frågan kan följande svar ges:

Klart jag skulle kunna säga en sverigedemokrat. Men det finns så klart sverigedemokrater i Uddebo även om de inte syns [skratt]. Men jag tror mer glidare och glassare och statusprylsmänniskor inte passar in så jättebra. IP nr 2

Ovan sägs att den som röstar höger eller som värderar erkännande i form av status och materiell framgång kan ha svårt att passa in i det samhälle som håller på att byggas. Samtidigt finns en medvetenhet om att flera politiska uppfattningar finns representerade i byn:

Så när jag säger att "det finns många här som tänker lika som jag”, så är jag ju väldigt lycklig över att det finns många som inte gör det också. Alltså, jag vill inte bo i en sekt, jag vill bo i ett samhälle där folk spretar åt alla möjliga olika håll. IP nr 11

Ett återkommande tema i intervjuerna är att isolering mellan sociala grupper sällan är möjlig i Uddebo (jfr Halfacree 2007). Vid intervjutillfället poängteras att såväl sverigedemokrater som asylsökande på Migrationsverkets boende återfinns på orten. Så kallade grindsamhällen må vara en aspekt av storstaden, men i Uddebo är villkoren annorlunda, enligt de intervjuade. Som påpekats av Forsberg, Lundmark och Stenbacka (2012) är det ofta en "demografisk myt" att se möten och mångfald som storstadens karaktäristika och likriktning som utmärkande för landsbygden. Myten riskerar att reproducera felaktiga uppfattningar om landsbygden som "lite efter" samt dölja heterogeniteten bland människor som lever och verkar på olika platser.

\section{Att verka i det kollektiva och förverkliga det individuella}

När Sennett (2019[2018]) analyserar hur urbana miljöer samspelar med människors förutsättningar för att leva tillsammans, framhåller han storstadens unika potential i form av den ”öppna staden”. Det urbana rummet erbjuder enligt Sennett möjligheter till möten mellan människor, som därmed kan utveckla respekt för skillnader. Den sortens sociologiska tankegång kan tvärtemot sitt syfte leda till en föreställning om den slutna landsbygden, en uppfattning som alltså sätts i fråga i de intervjuades berättelser.

Även om de intervjuade lyfter fram heterogeniteten i Uddebo och ser den som positiv, så finns det likheter inom den grupp som vi intervjuat. En gemensam nämnare är att flera har rest och bott på olika platser i Sverige och utomlands. I ljuset av detta framställer de Uddebo som en plats där de kunnat "rota" sig efter flera års boende och resande på andra ställen i världen. Vissa har bildat familj här: 
Jag fick ett tänk att det var förutbestämt. Jag tänkte: "Men nu har jag fött barnen hit, då får vi bo här ...”. Så jag slutade att tänka på att jag skulle bo någon annanstans, vilket var så himla skönt ... För jag har aldrig varit nöjd, flyttat runt och ... ”Nej, nu bor jag här, nu får jag se till att trivas ...”. IP nr 5

Uddebo har blivit en plats där man kan slå sig till ro. Några av de intervjuade pekar på fördelen med att de på landsbygden funnit ett liv som inte är så "utspritt" som i staden:

Att man är kvar där man är, det är det jag tycker, det är därför jag vill bo på landet, för jag vill ha mitt liv där jag är. Jag vill inte ha det utspritt, här jobbar jag, här bor jag, här umgås jag, att det finns samlat på något sätt. IP nr 3a

Även om det vackra landskapet kan framhållas som skäl för flytten till Uddebo, säger ingen av de intervjuade att det var anblicken av den lilla byn i dalgången som lockade. Ingen beskriver heller Uddebo som en sörgårdsidyll. Det som lockat har snarare varit att ha likasinnade nära och att tillhöra ett sammanhang. Uddebo kan vara den plats som de intervjuade sökt efter när de "letade efter ett ställe som var alternativt, en konstnärsplats" (IP nr 6), "en kulturmetropol på landet" (IP nr 8a) eller när de "ville bo någonstans där det fanns en gemenskap och där det var lite kreativt" (IP nr 4).

Förutom att Uddebo blivit en plats där kulturutövare inom flera olika områden samlas tycks det starkaste skälet för de intervjuade att bo på orten handla om "hållbarhet". I Uddebo går det att förverkliga en livsstil som är såväl ekonomiskt som ekologiskt hållbar. "Det här icke-ägandet" (IP nr 7) sägs ha utgjort en lockelse, där målet varit att bygga ett samhälle som är oberoende av det övriga samhällets ekonomiska och sociala system:

Det är dags att göra en förändring till något som är mer hållbart. Det behöver ske nu, nu, nu och hela tiden. IP nr 12

Uddebo präglas inte bara av ekologisk och ekonomisk hållbarhet, utan också "en hållbarhet i relationer och sociala skyddsnät" (IP nr 8b). Den geografiska närheten sägs underlätta för ortsinvånarna att ta hand om varandra. En intervjuperson säger att $\mathrm{i}$ Uddebo skulle nog alla ställa upp i kritiska situationer:

Jag tror att om det skulle komma en riktig kris [...] inte som coronakrisen, utan om någon skulle anfalla Sverige, om de skulle stänga av elen [...]. Jag har ingen kamin här, men jag skulle inte känna mig otrygg för jag vet att jag skulle kunna gå till vem som helst här som skulle hjälpa mig. Även om jag inte känner alla skulle jag känna mig trygg att flytta in hos vem som helst. Och jag tror att de skulle släppa in mig. IP nr 10

I intervjuerna berättas om hur det kollektiva i Uddebo utgör ett skäl till att vilja bo på platsen. En av de intervjuade beskriver Uddebo som en plats där "man tänker utanför 
sig själv” (IP nr 1). Livet i Uddebo kretsar då inte enbart kring individuella behov, utan även kring det gemensamma, som är till gagn för alla (jfr Beck 1998). Gula huset var det första gemensamma stora projektet i Uddebo för de nyinflyttade. Renoveringen av det fallfärdiga trevåningshuset började år 2009. I dag är det ett landmärke mitt i byn. Huset beskrivs som ett "vardagsrum" där alla kan mötas i olika aktiviteter:

Gula huset är en kollektiv plats [...] Det finns många olika kulturhus, men det roliga med Gula huset just tycker jag är att det är som byns vardagsrum. Alltså vi driver freeshopen där [...] Man vill att alla ska vara där. Melodikrysset, grötfrukost. Vi har en bio där. IP nr 11

I likhet med urbana alternativsamhällen, som exempelvis Christiania (Jarvis 2011), finns i Uddebo gemensamma kulturaktiviteter, allmänna måltider och en affär för byteshandel och återanvändning av kläder och andra bruksvaror - den så kallade "freeshopen". Här finns också den gemensamma bybastun, som några beskriver som den självklara platsen för samvaro av mer avslappnande karaktär.

När gemensamma aktiviteter kommer på tal uppmärksammar flera att det kanske viktigaste i Uddebo är den gemensamma odlingen, den så kallade samodlingen. Den står för den ekologiska hållbarhet som många eftersträvar och beskrivs som en systemkritisk, politisk handling som ska göra att "man klarar sig när apokalypsen kommer" (IP nr 3a). Medlemmarna menar att odlingen, förutom att bidra till kunskap och gemenskap, ger en omfattande skörd som täcker en del av deras livsmedelsbehov:

Jag hade inte kunnat odla så mycket själv, så jag är jätteglad att kunna gå och hämta grönkål, lök, vitlök och potatis [...]. Jag har en jordkällare där nere. Den är fylld med potatis. Den [samodlingen] ger en möjlighet att leva. Ip nr 7

Samodlingen skapar samhörighet och skörden är gynnsam för den som vill slippa att arbeta för brödfödan och i stället få tid till andra meningsfulla aktiviteter.

Även om flera framhåller de gemensamma aktiviteterna, säger några av de intervjuade att det var möjligheten att förverkliga egna projekt som lockade dem till platsen. En intervjuperson som bott i Uddebo i knappt ett halvår påpekar att hen måhända är "lite nyförälskad" (IP 8b) i den nya tillvaron, präglad av lust, lekfullhet och variation. Samtidigt uttrycker hen skuldkänslor över den nya vardagen: Är det verkligen tillåtet att ha ett så här roligt liv bortom lönearbetets alla plikter?

Jag har det nedärvt från mina föräldrar: Man ska ha anställning, jobb och det är det som värdesätter mig som människa. Att jag har en sysselsättning som också ger mig lön. Det är mer den här lathetsstämpeln. Jag håller ju inte med mig själv, men försöker förklara en känsla jag har av att det kan bli ... Ja, men som igår, jag åkte husbil i fyra timmar runt på landsbygden och så dumpstrade vi och sedan har jag spelat klarinett. Och sedan byggde jag med pinnar och sedan dansade jag ... Jag tänker att jag bara haft kul i två månader. IP nr 8b 
Återkommande är bilden av Uddebo som en plats där livet och vardagen kan bli meningsfulla. Intervjupersonen nedan säger sig i Uddebo kunna njuta av vardagens enkelhet bortom det kapitaliska arbetslivets hets och ständiga acceleration (jfr Rosa 2014[2012]), vilket är viktigt då livet så ofta ter sig meningslöst:

Jag känner att livet kan vara ganska meningslöst. Och det är tufft, och vi lever i en hård kapitalism. Det är ju liksom kämpigt för väldigt många. [...] Och då kan jag känna i den här lilla ... så vill jag hitta det meningsfulla. ”Nu ska jag cykla och jobba i freeshopen", det är det som berikar min vardag, att jag betyder något. Fast det kanske jag inte gör, men jag låtsas som det ... Eller om jag går och krattar lite på lekplatsen. IP nr 5

Intervjupersonen ovan har bott i Uddebo i ungefär tio år och är troligtvis inte längre kvar i den förälskelsefas som nämndes tidigare. Men oavsett om de intervjuade bott länge på orten eller bara en kortare tid, och oavsett om motiven för att leva och verka i Uddebo är möjligheten att förverkliga egna projekt eller att skapa något tillsammans, förenas de av strävan efter att göra livet meningsfullt.

Vad som i förstone kan framträda som antingen självutveckling och självförverkligande eller kollektiva mål, ska alltså inte enkelt tolkas som det ena eller det andra. Snarare tycks de intervjuade beskriva Uddebo som en plats där de kunnat finna konkreta livspraktiker som står i kontrast till den hårda kapitalismens meningslöshet. Detta kan sättas i samband med de grupper som Beck (1998) benämnde frihetens barn, alltså grupper som vänder samtidens osäkerhet till sin fördel. Dessa barn av en senare modernitet utvecklar en vardaglig livspolitik med alternativa levnadssätt som kan minska samtida etiska, ekologiska, sociala och ekonomiska dilemman. Om detta är en grundsats i det liv vi får skildrat för oss av de intervjuade, så är det tydligaste exemplet på en sådan livspolitik strävan efter att lönearbeta så lite så möjligt, en livspolitik som ofta anses stå i direkt opposition mot ett kapitalistiskt samhällssystem.

\section{Ett liv bortom lönearbetet}

Att lönearbeta framstår i intervjuerna ofta som ett nödvändigt ont. Enligt de intervjuade råder det i Uddebo ett visst samförstånd om "att folk har kommit fram till att jobba så lite som möjligt" (IP nr 11). Eller som en av dem säger: "Det är väl skönt så länge man slipper, tänker jag" (IP nr 3a). På så vis skapas tid för en livsföring som både gynnar det egna livet och lägger grunden för ett kommande postkapitalistiskt samhälle, eller som en annan intervjuperson säger: "Det gäller att göra en förändring så att våra barn får växa upp i ett samhälle där det finns en gemensam vilja att skapa en hållbar framtid" (IP nr 12). Genom att lönearbeta i mindre omfattning frigörs tid, och kanske är det just därför som det är så mycket aktivitet i Uddebo:

Jag tror att vi kände tidigt att "shit vad det händer mycket när så många människor inte förvärvsarbetar 40 timmar i veckan”. IP nr 9 
Syftet med att dra ner på lönearbetet kan alltså vara att få tid till gemensamma projekt eller att förverkliga drömmar, men det kan också vara ett sätt att dra ner på tempot, att vila och "bara" njuta av livet:

Och det faktum att många vill frigöra mycket tid till att göra vad de vill: pilla sig i naveln, leka med barn, vara ineffektiv. Det tycker jag är en väldigt hälsosam approach till livet ... IP nr 11

Att inte arbeta heltid kan beskrivas som ett sätt att värna om livet och hälsan. Men det kan också tolkas som en livspolitisk handling, där man formar en vardag som går stick i stäv mot det kapitalistiska arbetssamhällets krav på oss. Förhållningssättet kan påminna om det som Alfonsson (2020) finner i sin studie av unga behovsanställda. Till den alienerade situation som anställningsformen innebär intar några av dem Alfonsson intervjuat ett arbetskritiskt förhållningssätt och försöker hävda det möjliggörande i situationen. Att lönearbeta så få timmar som möjligt, och att därmed kunna beskriva sin vardag som mindre ockuperad av den marknadslogik där arbetskraften utnyttjas efter arbetsgivarens behov, tycks ge ett visst frihetsutrymme.

Bland våra intervjupersoner finns studerande och personer som har pension, egna företag eller anställningar i form av vikariat, allmän visstidsanställning eller tillsvidareanställning. Ett par av dem är behovsanställda. Av de anställda är det ingen som arbetar - eller vill arbeta - heltid. Ett arbetskritiskt förhållningssätt råder liksom hos dem som Alfonsson intervjuade i sin studie. Rätten att välja bort lönearbete tycks ge utrymme för ett meningsfullt liv. Och i detta livspolitiska sökande efter existentiell mening utgör egoism och solidaritet inte varandras självklara motsatser. Samtidigt är detta att dra ner på lönearbetet naturligtvis resurskrävande. Som en av de intervjuade säger:

När jag läser artiklar om Uddebo så står det att här kan man umgås, odla sin egen mat så man behöver inte jobba så mycket. Hela den där diskursen runt det. Det provocerar mig mycket. För jag kan inte betala mitt studielån med potatis. IP nr 10

Som Beck (1998:198) påpekade apropå frihetens barn så behövs det resurser om man ska våga sig på ett liv bortom det etablerade och utveckla en livspolitik med nya vanor och förhållningssätt. I det sammanhanget har Uddebo varit en attraktiv plats, eftersom husen var billiga när de intervjuade kom till orten. Som ett alternativ till lönearbete för att få pengar till mat kan också dumpstring vara en strategi:

Jag tror att många människor här lever nästan uteslutande på mat som de hittar gratis. Och det gör en stor skillnad om man kan spara hela sin matkasse. IP nr 8a

\section{Ett alternativsambälle i vardande}

Ovan har vi ringat in hur de intervjuade betraktar Uddebo i dag: som en plats bortom det kapitalistiska arbets- och konsumtionssamhället som möjliggör livspolitiska hand- 
lingar och existentiell mening. I sina beskrivningar av Uddebo jämför de intervjuade ofta med andra alternativsamhällen, vilket blir ett sätt att förstärka den egna platsens karaktär av möjlighetsrum för existentiell mening.

Några jämför med boendet i ekobyar, som sägs vara mer homogena och i högre grad definierade på förhand. Uddebo däremot beskrivs som en plats i ständig rörelse. Här samsas olika projekt som när som helst kan utvecklas till något nytt. Därför blir beskrivningarna bara ögonblicksbilder av en plats i ständig förändring. Lättare var det att skildra byns historia.

I intervjuerna sägs att det är detta svårfångade som gör det spännande att bo i Uddebo. Att leva på en plats i rörelse tycks alltså bli ett sätt att skapa existentiell mening (jfr Jackson 2005; Ekberg 2016). En intervjuperson berättar att vad som lockat hen till Uddebo var just att "det inte var så definierat vad den här platsen handlade om" (IP nr 4). En annan jämför med Christiania, som i motsats till Uddebo framstår som ett "stelnat" alternativsamhälle:

Om man tittar på Christiania i dag så är det kanske inte så lätt att komma in med en ny idé kanske. [...] Det har ju stelnat i en definition av vad är det här. Och där är inte Uddebo än. Det är det som är det mest spännande. IP nr 9

Vad vi troligtvis har att göra med här är så kallade motnarrativ (Andrews 2004), alltså berättelser som söker skapa alternativ till det etablerade, men vad är okänt. Vilken väg Uddebo ska ta är en öppen fråga, vilket alltså kan upplevas som meningsfullt i sig.

\section{Det framtida Uddebo - hot och möjligheter}

Om en fördel med Uddebo är att det är en odefinierad plats och ett alternativsamhälle i vardande, så går det samtidigt att skönja viss oro över rörelsens riktning och vissa farhågor för stelnande. Ökad inflyttning innebär ju större efterfrågan på bostäder och höjda huspriser som kan hota oberoendet av arbetssamhället, särskilt om främst kapitalstarka grupper söker sig till orten. De intervjuade kan kritisera marknadens styrformer, samtidigt som olika entreprenörskap växer sig starka i Uddebo, delvis baserade på idéer om alternativ livsföring och hållbarhet. Frågan är då: Ska dessa entreprenörskap främst gynna de bosatta i Uddebo eller tänks de locka andra människor till platsen?

\section{Hot mot oberoende...}

Som nämnts har många av de inflyttande i Uddebo konstnärlig utbildning eller bakgrund inom kultursektorn. Någon framhåller att utbildningsnivån överlag är hög: "Vi har ett väldigt högt humankapital i Uddebo" (IP nr 13). Att utbildningsnivån är hög bland de inflyttande framhålls inte bara som positivt. Risken finns att Uddebo blir en "hub" (IP nr 4) för kulturellt kapitalstarka grupper (jfr Bourdieu 2004[1979]), som försörjer sig på sina idéer och söker attraktiva platser som kan ge inspiration för stunden (jfr Florida 2006[2002]). För som så ofta när kapitalstarka grupper samlas på en viss plats, finns risk för gentrifiering som minskar möjligheten att bo billigt (Thörn \& Holgersson 2014). Att sätta Uddebo på kartan som konstnärsby kan med andra ord försvåra ett billigt boende på platsen. 
Som konstnär är jag medveten om att jag är en stor del i att gentrifiera den här platsen själv, men att jag liksom gentrifierar bort mig själv. Det är så krasst och cyniskt och tråkigt. IP nr 4

Risken med den gentrifiering som kan drivas fram är alltså att marknadsvärdet på husen ökar. Därmed riskerar den arbetskritiska idén om Uddebo som en plats där det är billigt att leva och verka gå förlorad. I intervjuerna påtalas att en sådan rörelse kan driva bort människor som bor i Uddebo, grupper som bidrar till alternativssamhället eller till platsens heterogenitet:

Men det kan ju hända att gentrifieringen går för långt, att folk tröttnar och inte har råd. Det blir för dyrt. IP nr 11

En annan aspekt som förefaller hota Uddebo som alternativsamhälle hör samman med en gängse föreställning om landsbygdsutveckling: strävan att bli ett turistmål för att öka inflyttningen och sätta fart på den ekonomiska utvecklingen (jfr Carlén 2017). Nedan framhålls vikten av att Uddebo inte blir ett "exotiskt" turistmål, vilket nästan betraktas som motsatsen till hållbar utveckling, eftersom den sortens inkomstkällor är alltför konjunkturberoende:

Det som jag tycker är mindre intressant och som är en utveckling på landsbygden överhuvudtaget, är att det man ska få in sina pengar på är turism. Att det ska bli ett turistmål. [...] När turisterna slutar komma, då har man inte de där jobbtillfällena längre. Man kommer fortfarande behöva äta och man kommer fortfarande behöva ta hand om sina hus. IP nr $3 \mathrm{a}$

Arrangemang av konstnärsrundor, festivaler, teaterföreställningar och konserter eller odling av frukt och grönsaker till försäljning är liksom det nystartade surdegsbageriet verksamheter som skapar förutsättningar för att leva och verka på platsen. Men enligt somliga av intervjupersonerna riskerar den sortens projekt att leda till att Uddebo reduceras till ett mål för utomstående besökare. En lösning på dilemmat blir, enligt den intervjuade nedan, att se till så att Uddeboborna själva driver utvecklingen och får del av den ekonomiska behållningen:

Det är en enorm skillnad när det kommer in internationellt kapital och spekulerar: "Var finns det bra marknadslägen?" Och investerar i lokaler och sedan lyfter vinsten någon helt annanstans. IP nr 9

Bland de intervjuade finns emellertid olika uppfattningar om vad och vilka grupper som platsens verksamheter främst ska gynna. En annan fråga på samma tema (oberoendet av marknaden och arbetssamhället) är huruvida de kollektiva projekten ska finansieras med externa medel eller bekostas av de boende själva. I intervjuerna framkommer att Uddebo under årens lopp fått medel beviljade för olika projekt 
inom exempelvis byggnadsvård, miljöteknik, projektledning, kulturarrangemang och konstnärsprojekt. Pengar har kommit från det allmänna, från frivilligorganisationer eller från olika privata fonder. En av de intervjuade beskriver detta med de stolta orden: "Det finns ett tiotal personer här som har svart bälte i att skriva ansökningar" (IP nr 13).

Vissa är tveksamma till att söka externa medel, eftersom dessa kan innebära en styrning som gör att friheten att definiera och utveckla projekt går förlorad. Dessa röster hävdar att nyskapande idéer tvingas in i efterfrågade syften. Finansiärerna ställer krav på redovisning, återrapportering och inte minst måluppfyllelse. Att definiera projektets syfte på förhand beskrivs som motsatsen till idealet om att låta verksamheter växa fram organiskt.

Jag tror mycket av hela konceptet har byggt på att vi gjort det utan stor budget. Vi har gjort det genom att samarbeta. Det har vuxit fram organiskt. Det har inte varit styrt. Det har varit fritt, flödande åt alla möjliga håll. Det har inte gått att detaljstyra det, planera det. IP nr 8a

Att underkasta sig ansökningsförfarandets logik, där tydliga mål ska redovisas på förhand för att sedan kunna följas upp, riskerar alltså att medföra kompromissande med de "alternativa" idealen. För enligt intervjupersonen ovan är det just denna frihet som lagt grunden till viljan att gemensamt bygga en fungerande och meningsfull vardag. Alternativsamhället i ständig rörelse låter sig med andra ord inte definieras i planer om mål och resultat, vilka så ofta präglar det övriga samhället.

\section{... men ändå ett efterföljansvärt exempel}

Ovan tog vi upp några hot mot möjligheten att etablera ett alternativsamhälle på landsbygden som inte är så beroende av det övriga samhällets ekonomiska system och normer. Studier av urbana alternativsamhällen har pekat på likartade dilemman i fråga om möjligheten att forma en livspolitik utanför etablerade sociala och ekonomiska system. I Christiania har politiker använt direkta påtryckningar och styrmedel i form av lagstiftning och offentliga resurser för att omforma och "strömlinjeforma" platsen och livsformen. I exemplen från Uddebo handlar det mer om oavsiktliga konsekvenser i form av en inträngande marknad eller externa medel.

Enligt Amouroux (2011) förekommer vid sidan av "externa normaliseringsprocesser" även "interna normaliseringsprocesser" i alternativssamhällen. Som en effekt av yttre påtryckningar kan interna strider uppkomma om makten att definiera vad platsen ska vara och vilka eftergifter som ska göras mot exempelvis välfärdsstaten. Risken med sådana maktstrider är, enligt Amouroux, att exempelvis unga eller kulturellt kapitalsvaga grupper lätt hamnar vid sidan av alternativsamhällets beslutsprocesser. Att den här sortens komplikationer kan uppstå känns igen från forskning om sociala rörelser, som visat hur resursstarka individer kan bli talespersoner för resurssvaga grupper, inte sällan genom att framställa sig som en "altruistisk" röst (Peterson 2019). I Uddebo påtalas liknande dilemman apropå ansökningar om externa medel. Faran med 
ansökningsförfarandet är att det blir högutbildade med stor vana att uttrycka sig som ges företräde att bestämma Uddebos framtida riktning.

De hot som identifieras vad gäller Uddebos utveckling rör alltså inte bara marknadens intrång eller ekonomiska styrmedel. De innefattar även frågor om demokrati, delaktighet och beslutsfattande. Hur kan det undvikas att kulturellt kapitalstarka automatiskt får företräde i praktiken? De som bott i stora kollektiv har erfarenhet från utarbetade och mer formaliserade kollektiva beslutsprocesser, som vissa av dem uppskattat. Andra kan tycka att informella beslutsprocesser är just vad som gör Uddebo attraktivt, att man helt enkelt tar problemen när de dyker upp:

"Hur kan vi komma fram till något så att det blir bra?" Och att vi vågar prata om saker, och det tror jag att vi gör mycket här. IP nr 7

"Det gemensamma" beskrivs ofta av intervjupersonerna som ett signum för Uddebo. Men den omtanke och närhet som vi tidigare såg beskrivas i sociala hållbarhetstermer kan också sättas i samband med social kontroll och intolerans. Och här kan konflikter uppstå. Några av de intervjuade säger att det var svårt att inte ställa upp de planerade arbetsdagarna när Gula huset skulle renoveras, även om småbarnen väntade, dagen föregåtts av sömnlösa nätter eller andra aktiviteter lockade. Samodlingen kan utlösa diskussioner om hur skörden ska fördelas: lika, utifrån behov eller utifrån arbetsinsats? Och vilka regler ska gälla i den gemensamma bastun för att alla ska trivas?

Jarvis (2011) har beskrivit hur social tillhörighet och gemensamma praktiker som att dela måltider skapar en känsla av tillhörighet och underlättar balans mellan exempelvis familjeliv och arbete i Christiania. Hon pekar på hur christianiterna lyckats utveckla en harmonisk tillvaro bortom det hypermoderna samhället. Men hon understryker att dessa konkreta praktiker medför slitningar och risk för exkludering. När beslutsmöten hålls sent på kvällen är det lätt att ensamstående föräldrar utestängs eftersom de inte kan komma ifrån. Likaså kan brist på transparens i besluten bidra till att olika informella lösningar utvecklas (se även Starecheski 2011).

Intervjuerna vittnar om att livspolitiken i Uddebo kan ge mening i människors liv, men också medföra spänningar i fråga om hur den konkret ska utformas och vilken riktning livet på platsen ska ta. Ekberg (2016) såg i sin studie av 1970-talets urbana och rurala alternativa samhällen att den här sortens konflikter kunde uppstå. I sin vilja att skapa ett framtida och mer solidariskt socialt sammanhang var grupperna enligt Ekberg ofta ovilliga att medge interna oenigheter, vilket försvårade konfliktlösning.

Med utgångspunkt i Christiania poängterar Jarvis (2011) att maktstrider och demokratiska dilemman inte ska hindra politiker, arkitekter eller stadsplanerare från att se hur visioner och praktiker i alternativsamhällen kan erbjuda både social, ekonomisk och ekologisk hållbarhet. I detta sammanhang kan forskare synliggöra hur individuella problem får en lösning i kollektiva praktiker och belysa upplevelser av existentiell mening bortom vardagens stress. Dessa beskrivningar kan i förläningen inspirera aktörer inom innovation till att forma ekologiskt, ekonomiskt och socialt hållbara livsmiljöer. För de intervjuade tycks behovet av att forma ett hållbart samhälle ha blivit särskilt 
påtagligt i samband med den kris som uppstått till följd av coronapandemin. Krisen förefaller utgöra ett existentiellt imperativ (Jackson 2005), där Uddebo synliggörs som ett möjlighetsrum för meningsskapande, där lönearbete och konsumtion begränsas och där gemensamma åtaganden bidrar till existentiell rikedom (jfr Bengtsson \& Flisbäck 2020).

Vi lever här så som coronan visar att vi måste göra. Vi måste ändra våra liv till ett mer hållbart leverne. Och då blir det ju det när man inte konsumerar [...]. Och det här att man kan vara kvar hemma och det är bra det med. Det rör sig här med. Det är ett annat liv, som blir mer intressant än att bara se om sitt eget. IP nr 7

\section{Avslutning}

När vi analyserat berättelser om vad som lockat de intervjuade att bo och leva i Uddebo har vi anlagt ett existenssociologiskt perspektiv. Existenssociologin uppmärksammar hur sociala fenomen är relaterade till människans sökande efter mening och livsmål, men också till hennes försök att hantera livets obegriplighet inklusive hennes egen död (Douglas \& Johnson 2010[1977]). Hennes försök i den vägen utgår från tidigare livserfarenheter, men formas också av tankar, planer och förhoppningar om framtiden (Flisbäck 2014). I artikeln har dessa tidsdimensioner analyserats i relation till en gemensam berättelse om platsens historia, samtid och framtid snarare än till de intervjuades livshistoria. Vi har tagit del av ett gemensamt narrativ om hur den nuvarande platsen formats utifrån en historia om Uddebo från idyll via förfall till en plats där det finns möjlighet att bygga ett framtida hållbart samhälle som kan bestå efter de intervjuades egen livstid.

Narrativen om vad Uddebo en gång varit utgör en tolkningshorisont för de intervjuade inom vilken deras individuella existentiella meningssökande placeras. Den gemensamma historien om Uddebo tas till intäkt för att den livspolitik som utformas på platsen är autentisk. På så vis tolkas också livspolitiken som hållbar: nuvarande praktiker och visioner har sin grund i en kollektivism som alltid hört till platsen. Samtidigt finns en förhoppning om att Uddebo även i framtiden ska förbli ett alternativsamhälle i ständigt vardande, vilket de intervjuade beskrivit som ett utmärkande drag för dagens Uddebo. Ur ett hållbarhetsperspektiv kan den här sortens motstånd mot det definierbara betecknas som strävan efter resiliens, en hållbarhet som i Sennetts urbansociologiska perspektiv är ett system som "fjädrar tillbaka" och utmanar genom att "lita till omgestaltning" (2019[2018]:351). Att låta vardagens praktiker vara i rörelse kan ses som en grundbult i ett existentiellt meningsskapande där individer och grupper söker bejaka och öppna sig för livet obegriplighet, ovisshet och förändring (Jackson 2005; jfr Rosa 2020[2018]).

I linje med Becks (1998) beskrivning av frihetens barn tycks de intervjuade således vilja hantera samtidens osäkerhet genom att se öppenhet, ta vara på rörligheten i det obeständiga och se möjligheter i risksituationer. Med sikte på att själva få bestämma över sin tid och framtid, samt att finna kollektiva öppningar på individuella problem, 
tycks de ha utvecklat en vardaglig livspolitik på landsbygden, bortom det kapitalistiska samhällets hets, som ger tänkbara svar på deras existentiella sökande. Samtidigt kan livspolitiken inte försiggå helt utanför det övriga samhällets ekonomiska och sociala villkor, vilket tycks utgöra ett hot mot byggandet av ett alternativsamhälle på landsbygden.

Livspolitiska handlingar innefattar en estetisk, etisk och politisk iscensättning av det egna livet som upplevs existentiellt meningsfullt. Konkret kan det handla om att dumpstra, att odla, att göra fint på en gemensam lekplats eller att gå i skogen. Men det innefattar också möten och närhet till olika personer och sociala grupper. Här menar de intervjuade att landsbygden har en unik potential. Även om de sökt sig till Uddebo för att möta likasinnade, uppskattar de heterogeniteten på orten. Även om flera av de intervjuade är verksamma inom kulturområdet kan Uddebo således inte beskrivas som en nod för en kulturellt kapitalstark elit som befinner sig i ständig geografisk rörelse, alltså som en plats endast till för en så kallad kreativ klass (Florida 2006[2002]). Snarare möjliggör platsen olika sociala kontakter. Det framstår som ett Sverige i miniatyr där det också är möjligt att slå rot. På så vis tycks de intervjuade aktivt invända mot ett mobilitetsimperativ om att landsbygden bör överges eftersom ingen utveckling kan ske där (Farrugia 2016; Uddbäck 2021). Men här ska vi inte glömma att de intervjuade tidigare rört sig mellan olika platser i världen och ofta smakat på det storstadsliv som framhålls som eftersträvansvärt enligt samtidens kulturella normer. Kanske är de tillräckligt "rika" vad gäller redan gjorda erfarenheter för att ha råd att utmana dominerande mobilitetsimperativ och normer om storstadens fördelar.

I den livspolitik de intervjuade utvecklat i Uddebo eftersträvas alltså en meningsfull vardag i ett liv som annars kan upplevas som meningslöst. Väsentligt är att se varje dag som ny, att njuta av enkelheten bortom det kapitaliska arbetslivets hets och att eftersträva ett oberoende samhälle som ter sig robust både för kommande generationer och i kristider, såsom under coronapandemin. De visioner och praktiker som skapats i detta alternativsamhälle på landsbygden kan med andra ord både ge mening i nuet och peka på hur ett hållbart samhälle bortom det nuvarande kan ta form. På så vis kan kanske Uddebo både inspirera till innovation av socialt hållbara livsmiljöer samt väcka idéer för så kallad landsbygdsutveckling. Halfacree (2007:138) har i det sammanhanget pekat på krisens särskilda betydelse: "Man kan hävda att radikala visioner har störst potential att tränga in i det allmänna medvetandet i kristider, då en öppning tycks uppstå.” Men frågan om vilken spridning en sådan livspolitik kan få i bredare lager kan troligtvis besvaras först långt efter det att pandemin är över. 


\section{Referenser}

Alfonsson, J. (2020) Alienation och arbete. Unga behovsanställdas villkor i den flexibla kapitalismen. Lund: Arkiv förlag.

Andrews, M. (2004) "Counter-narratives and the power to oppose", 1-6 i M. Bamberg $\&$ M. Andrews (red.) Considering counter narratives. Narrating, resisting, making sense. Amsterdam: John Benjamins Publishing Company. https://doi.org/10.1075/ $\sin .4 .02$ and

Atkinson, P. \& D. Silverman (1997) "Kundera's immortality. The interview society and the invention of the self", Qualitative Inquiry 3 (3):304-325. https://doi. org/10.1177/107780049700300304

Amouroux, C.S. (2011) "Normalisation within Christiania", 235-262 i H. Thörn, C. Wasshede \& T. Nilson (red.) Space for urban alternatives? Christiania 1971-2011. Stockholm: Gidlunds förlag.

Baert, P., M. Morgan \& R. Ushiyama (2021) "Existence theory. Outline for a theory of social behaviour", Journal of Classical Sociology 22 (1):7-29. https://doi. org/10.1177/1468795X21998247

Beck, U. (1998) Democracy without enemies. Cambridge: Polity Press.

Beck, U. (2000[1986]) Risksambället. På väg mot en annan modernitet. Göteborg: Daidalos.

Bengtsson, M. \& M. Flisbäck (2020) "Coronakrisen synliggör behovet av att analysera arbete som ett kall", Arbetsmarknad \& Arbetsliv 26 (3):70-73.

Bengtsson, M. \& M. Flisbäck (2021) "Illuminating existential meaning. A new approach in the study of retirement", Qualitative Sociology Review 17 (1):196-214. https://doi.org/10.18778/1733-8077.17.1.12

Berglund, A.-K., S. Johansson \& I. Molina (red.) (2005) Med periferien i sentrum. En studie av lokal velferd, arbeidsmarked og kjønnsrelasjoner i den nordiske periferien. Alta: Norut NIBR Finnmark.

Bertaux, D. (1981) Biography and society. The life history approach in the social sciences. Berkeley: University of California Press.

Bourdieu, P. (2004[1979]) Distinction. A social critique of the judgment of taste. London: Routledge.

Brorström, S. \& A. Parment (2017) Attraktiva platser bortom urbanisering och tillväxt. En studie av hållbar utveckling. Lund: Studentlitteratur.

Carlén, M. (2017) Från avkrok till ett prioriterat turistmål. En studie av Glasets Hus och hur invånarna, företagarna och politikerna tillsammans satte Limmared på turistkartan. Borås: Högskolan i Borås.

Charmaz, K. (2014) Constructing grounded theory. London: Sage.

Cras, P. (2017) Landsbygdssambällets medborgarskap. En studie av organisering av service och infrastruktur i gränslandet mellan det ideella, kommersiella och politiska. Uppsala: Sveriges Lantbruksuniversitet.

Douglas, J.D. \& J.M. Johnson (red.) (2010[1977]) Existential sociology. Cambridge: Cambridge University Press. 
Ekberg, K. (2016) Mellan flykt och förändring. Utopiskt platsskapande i 1970-talets alternativa miljö. Lund: Historiska institutionen, Lunds universitet.

Eurofound (2019) "European jobs monitor 2019", https://publications.jrc.ec.europa. eu/repository/bitstream/JRC117824/ef19036en_1.pdf_(hämtningsdatum 28 april 2021).

Farrugia, D. (2016) "The mobility imperative for rural youth. The structural, symbolic and non-representational dimensions rural youth mobilities", Journal of Youth Studies 19 (6):836-851. https://doi.org/10.1080/13676261.2015.1112886

Flisbäck, M. (2014) När livet går bort, när livet kommer till. Existenssociologiska betraktelser av konstnärligt arbete, familjebildning och anhörigförlust. Lund: Studentlitteratur.

Florida, R. (2006[2002]) Den kreativa klassens framväxt. Göteborg: Daidalos.

Forsberg, G., M. Lundmark \& S. Stenbacka (2012) Demografiska myter. Föreställningar om landsbygden - mer myter än faktiska fakta. Stockholm: Öhrlings Pricewaterhouse Coopers AB.

Halfacree, K. (2007) "Trial by space for a 'radical rural'. Introducing alternative localities, representations and lives", Journal of Rural Studies 23 (2):125-141. https:// doi.org/10.1016/j.jrurstud.2006.10.002

Heidegger, M. (2013[1927]) Vara och tid. Göteborg: Daidalos.

Herold, L. (2020) "I Uddebo värderas tid högre än pengar", Dagens Nyheter 12 april 2020.

Hideng, Y. (2021) "Uddebos befolkning växte mest i kommunen”, Svenljunga Tranemo Tidning 17 mars 2021.

Jackson, M.D. (2005) Existential anthropology. New York: Berghahn Books.

Jarvis, H. (2011) "Alternative visions of home and family life in Christiania. Lessons for the mainstream", 156-180 i H. Thörn, C. Wasshede \& T. Nilson (red.) Space for urban alternatives? Christiania 1971-2011. Stockholm: Gidlunds förlag.

Kotarba, J.A. (2002) "Baby boomer rock'n'roll fans and the becoming of self", 103-126 i J.A. Kotarba \& J.M. Johnson (red.). Postmodern existential sociology. A sociology of everyday life. Walnut Creek: AltaMira Press.

Lefebvre, H. (1991[1974]) The production of space. Oxford: Basil Blackwell.

Massey, D. (2007) World city. Cambridge: Polity Press.

Nyberg, D. (2019) "Det omöjliga blev möjligt i Uddebo. Från utflyttning och förfallna hus till bostadsbrist och nybyggen”, Tidningen Västsverige 20 juni 2019.

Peterson, A. (2019) "Ai Weiwei and JR. Political artists and activist artists and the plight of refugees", Journal of Mediterranean Knowledge 4 (2):183-202. https://doi. org/10.26409/2019JMK4.2.12

Rosa, H. (2014[2012]) Acceleration, modernitet och identitet. Tre essäer. Göteborg: Daidalos.

Rosa, H. (2020[2018]) Det vi inte kan råda över. Om vårt förhållande till världen. Göteborg: Daidalos.

Rönnblom, M. (2016) "För en platsens politik", Glänta 3-4.

Sennett, R. (2019[2018]). Den öppna staden. En etik för byggande och boende. Göteborg: Daidalos. 
Starecheski, A. (2011) "Consensus and strategy. Narratives of naysaying and yeasaying in Christiania’s struggles over legalisation”, 263-287 i H. Thörn, C. Wasshede \& T. Nilson (red.) Space for urban alternatives? Christiania 1971-2011. Stockholm: Gidlunds förlag.

Squire C., M. Andrews \& M. Tamboukou (2008) "Introduction. What is narrative research?", 1-21 i I.M. Andrews, C. Squire \& M. Tamboukou (red.) Doing narrative research. London: Sage. https://dx.doi.org/10.4135/9780857024992.d2

Thörn, C. \& H. Holgersson (red.) (2014) Gentrifiering. Lund: Studentlitteratur.

Tillmar, M. (2019) "Socialt entreprenörskap och utveckling av landsbygder", 221-242 i K. Wennberg (red.) Entreprenörskap för en levande landsbygd. 15 texter om landsbygdsutveckling och entreprenörskap i Norrland. Växjö: Familjen Kamprads stiftelse.

Tuan, Y.-F. (2011) Space and place. The perspective of experience. Minneapolis: University of Minnesota Press.

Uddbäck, H. (2021) Att stanna kvar. Arbete, plats och mobilitet i småstaden. Göteborg: Institutionen för sociologi och arbetsvetenskap, Göteborgs universitet.

Uddebo Uddetopia (2021) "Småhusbyn och imaginariet", http://uddebo.uddetopia.com/ foretag-foreningar/future-utopia-community-key (hämtningsdatum 28 april 2021).

Vallström, M. (red.) (2014) När verkligheten inte stämmer med kartan. Lokala förutsättningar för hållbar utveckling. Lund: Nordic Academic Press.

Vetenskapsrådet (2017) God forskningssed. Stockholm: Vetenskapsrådet.

Åkerman, A. (2020) "Reportage: Resan till det nya landet”, Arkitektur 4:48-59.

\section{Tillkännagivanden}

Artikel är författad inom ramen för projektet "Hybrida organisationer som verktyg för hållbar platsutveckling”, som är finansierat av Centrum för välfärdsstudier (CVS) vid Högskolan i Borås. Tack till docent Mattias Bengtsson och filosofie doktor Maja Cederblad vid Göteborgs Universitet, Peter Serrander vid Science Park Borås samt tre anonyma bedömare för viktiga synpunkter på manuskriptet.

\section{Författarpresentationer}

Marita Flisbäck är professor i sociologi vid Högskolan i Borås. Hennes forskning berör erkännande och existentiell mening i familje- och arbetsliv med särskilt fokus på konst- och kultursektorn, pensionering och åldrande, samt status och erkännande i yrkeslivet. Analyserna utgår ofta från existenssociologiska perspektiv samt feministiska och kultursociologiska klassperspektiv.

Margareta Carlén är filosofie doktor i pedagogik vid Högskolan i Borås och verksamhetschef vid FoU Sjuhärad Välfärd, ett kompetenscentrum för forskning och utveckling inom välfärdsområdet. Carlén har bland annat forskat om lär- och omställningsprocesser i arbetslivet samt olika faktorer som leder till socialt, ekonomiskt och ekologiskt hållbar utveckling i landsbygdskommuner. 


\section{Kontaktuppgifter författare}

Marita Flisbäck

Akademin för vård, arbetsliv och välfärd, Institutionen för arbetsliv och välfärd, Högskolan i Borås

50190 Borås

marita.flisback@hb.se 